\title{
Sequence conservation of microsatellites between Bos taurus (cattle), Capra hircus (goat) and related species. Examples of use in parentage testing and phylogeny analysis
}

\author{
LAURENT PÉPIN, YVES AMIGUES†, ANDRÉE LÉPINGLE, JEAN-LUC BERTHIER \\ ALBERT BENSAID§ \& DANIEL VAIMAN* \\ Laboratoire de Génétique Biochimique et de Cytogénétique and † Laboratoire des Groupes Sanguins, INRA-CRJ, 78350 \\ Jouy-en-Josas, $\ddagger$ Ménagerie du Jardin des Plantes, 57 rue Cuvier, 75231 Paris and $\$$ CIRAD-EMVT, 10 rue Pierre Curie, \\ 94704 Maison-Alfort, France
}

\begin{abstract}
A panel of 70 bovine microsatellites was tested for amplification from goat DNA. Forty-three could be successfully amplified by PCR, 20 of which were tested for polymorphism. Three were applied for parentage testing in goat families and their exclusion probability evaluated. Fourteen were cloned and sequenced from goat DNA, and goat and bovine sequences were compared to evaluate interspecific conservation. Correlation between the structure of the dinucleotide repeat and the number of alleles was studied and indicated that interruption(s) in the repeat could explain the difference in the levels of polymorphism between the two species. This study provides a valuable in vivo clue to the mechanism generating polymorphism in microsatellites. Sequence conservation was also observed for several microsatellites with two wild species of Bovidae, Nilgai (Boselaphus tragocamelus) and Himalayan Tur (Capra cylindricornis), and with one species of Cervidae, the fallow deer (Cervus dama).

This study showed that an estimated 40 per cent of the microsatellites isolated from cattle will prove useful to study the caprine genome and to characterize economically important genetic loci in this species. Moreover, bovine microsatellites were shown to constitute very useful tools for the study of genetic diversity of the Artiodactyla.
\end{abstract}

Keywords: goat, interspecific priming, intraspecific genetic variation, microsatellites, polymorphisms.

\section{Introduction}

Ninety-four per cent of all goats are nowadays found in the developing countries of Asia and Africa, and constitute an important source of milk and proteins in these countries. Furthermore, in developed countries, goats are of economic importance and selection of potentially interesting parents at the gene level is already used for milk proteins such as $\alpha-S 1$ casein (Leroux et al., 1990). Therefore, progress in knowledge about the genome of this species is very useful and could bring a rapid improvement of goat breeds and an increase in performance. As very little funding is granted to study the goat genome compared with cattle and sheep, exploitation of genetic markers

*Correspondence. isolated from these closely related species (given that they can be used in goat) would have a big impact.

The versatility of microsatellite markers (tandem repeat motifs of one to five base pairs), makes them the ideal tools for genetic mapping, as well as valuable tag sequences for physical mapping. Also, their generalized use has allowed an increased knowledge of the genetic map of different vertebrate genomes. Microsatellites have been found throughout eukaryotic organisms, and particularly in different classes of vertebrates (mammals: Cornall et al., 1991; Schlötterer et al., 1991; Ellegren et al., 1992; Weissenbach et al., 1992; birds: Crooijmans et al., 1993; fish: Estoup et al., 1993).

In the past few years, with the development of many new microsatellite markers, bovine and ovine genetic mapping has made rapid progress (Moore et al., 1992; Vaiman et al., 1992, 1994b; Kaukinen \& Varvio, 
1993). This is evidenced by the building of the first linkage maps (Barendse et al., 1993a, 1993b), and the finding of markers associated with diseases such as weaver (Georges et al., 1993a), morphological features such as poll (Georges et al., 1993b) or interesting Economic Trait Loci (ETL) such as Booroola (Montgomery et al., 1993). Comparatively, knowledge about the genome of the third economically important Bovidae species, goat, has increased less rapidly. Nevertheless, the apparent chromosomal similarity between cattle, sheep and goat (Hayes et al., 1991) suggests that markers developed in one of the three species could be readily used in the other two. Between cattle and sheep, such a possibility (Kemp et al., $1993 \mathrm{~b}$ ), as well as synteny conservation has been demonstrated (Vaiman et al., 1994a). However, no statistical data on a sufficiently large number of microsatellite markers are available to draw a general conclusion. The purpose of this study is to evaluate a large number of cattle microsatellites to determine the sequence conservation and to explore the possiblity of utilizing these markers in goat.

In this paper, primers derived from 70 bovine microsatellite flanking sequences (Vaiman et al., 1994b), were used to amplify the goat corresponding loci. Forty-one amplification products could be obtained, of which 14 were cloned and sequenced. The possibility of using these microsatellites for goat parentage testing and population polymorphism analysis was evaluated.

\section{Materials and methods}

\section{Animals and DNA preparation}

Sixty unrelated goats from four different breeds (12 Poitevine, 12 Saanen, 12 Alpine, 12 Guinean, 12 Sahelian, 12 Guadeloupean creolous), were used to estimate the allelic frequencies of each microsatellite. For population studies, the allelic frequencies were estimated from a panel of 30 animals for the Alpine, Saanen and Poitevine breeds and from 12 animals for each of the other breeds. Mendelian codominant transmission of the alleles was ascertained on a family of 15 creolous goats composed of a sire, seven dams and their progeny.

DNA was prepared from $20 \mathrm{~mL}$ blood samples collected on EDTA, according to Jeanpierre (1987) or from $200 \mathrm{~mL}$ of frozen blood according to Cui et al. (1989).

\section{PCR conditions}

PCR typing of animals to estimate allelic frequencies was carried out on $100 \mathrm{ng}$ of genomic DNA in a $10 \mu \mathrm{L}$ reaction with $25 \mu \mathrm{M}$ dGTP, dCTP, dTTP, $2.5 \mu \mathrm{M}$ of $\mathrm{dATP}$ and $0.1 \mu \mathrm{L}\left[{ }^{35} \mathrm{~S}\right] \mathrm{dATP}$ (Amersham, $1000 \mathrm{Ci}$ / mmol, $10 \mu \mathrm{Ci} / \mu \mathrm{L}$ ) with a Taq DNA Polymerase kit purchased from Promega $(1.5 \mathrm{~mm}$ final magnesium concentraton). After a first step of denaturation at $94^{\circ} \mathrm{C}$ during $5 \mathrm{~min}, 30$ cycles of amplification were realized $\left(15 \mathrm{~s} 94^{\circ} \mathrm{C}, 15 \mathrm{~s} 55^{\circ} \mathrm{C}, 20 \mathrm{~s} 72^{\circ} \mathrm{C}\right)$ using a Perkin-Elmer Cetus 9600 thermocycler. PCR products were then loaded with $5 \mu \mathrm{L}$ of loading buffer $(0.25$ per cent Bromophenol Blue, 0.25 per cent Xylene cyanol, in 95 per cent deionised formamide) on a 5 per cent polyacrylamide $/ 7.5 \mathrm{M}$ urea denaturing gel, and run for $2 \mathrm{~h}$ at $1500 \mathrm{~V}$. The gels were dried and autoradiographed overnight at room temperature.

\section{Cloning and sequencing of PCR products}

After standard PCR procedures using bovine primers, goat amplification products were extracted once with phenol-chloroform, precipitated, phosphorylated with T4 Polynucleotide kinase (Boehringer), extracted again with phenol-chloroform, precipitated and ligated into the SmaI site of dephosphorylated PUC 18 using T4 DNA ligase (BRL). Four independent clones from two different animals were sequenced for each microsatellite using an ABI 373A automated sequencer.

\section{Sequence analysis and calculations}

Sequence alignments between the sequences of bovine, goat and other species and database searches were realized using the 'gap' and 'fasta' algorithms of the GCG software package, respectively (Devereux et al., 1984). When the difference in the microsatellite size was too large to make an alignment between the two species, the flanking sequences were aligned without including the primers. The similarity coefficients presented in Table 2 were always calculated without the primers and without the dinucleotide repeat.

PIC (Polymorphic Information Content) was calculated in the total number of individuals according to Botstein et al. (1980). Exclusion probabilities were calculated according to Hanset (1975).

\section{Results and discussion}

\section{Sequence comparison between cattle, goat and other species of Artiodactyla}

Table 1 presents a list of the 70 bovine microsatellite markers utilized in this study. All these loci were tested by PCR with goat DNA. The quality of the PCR product was rated by a number between 1 and 4 (1: strong amplification with only one band (or two to account for heterozygous animals) of the expected size; 


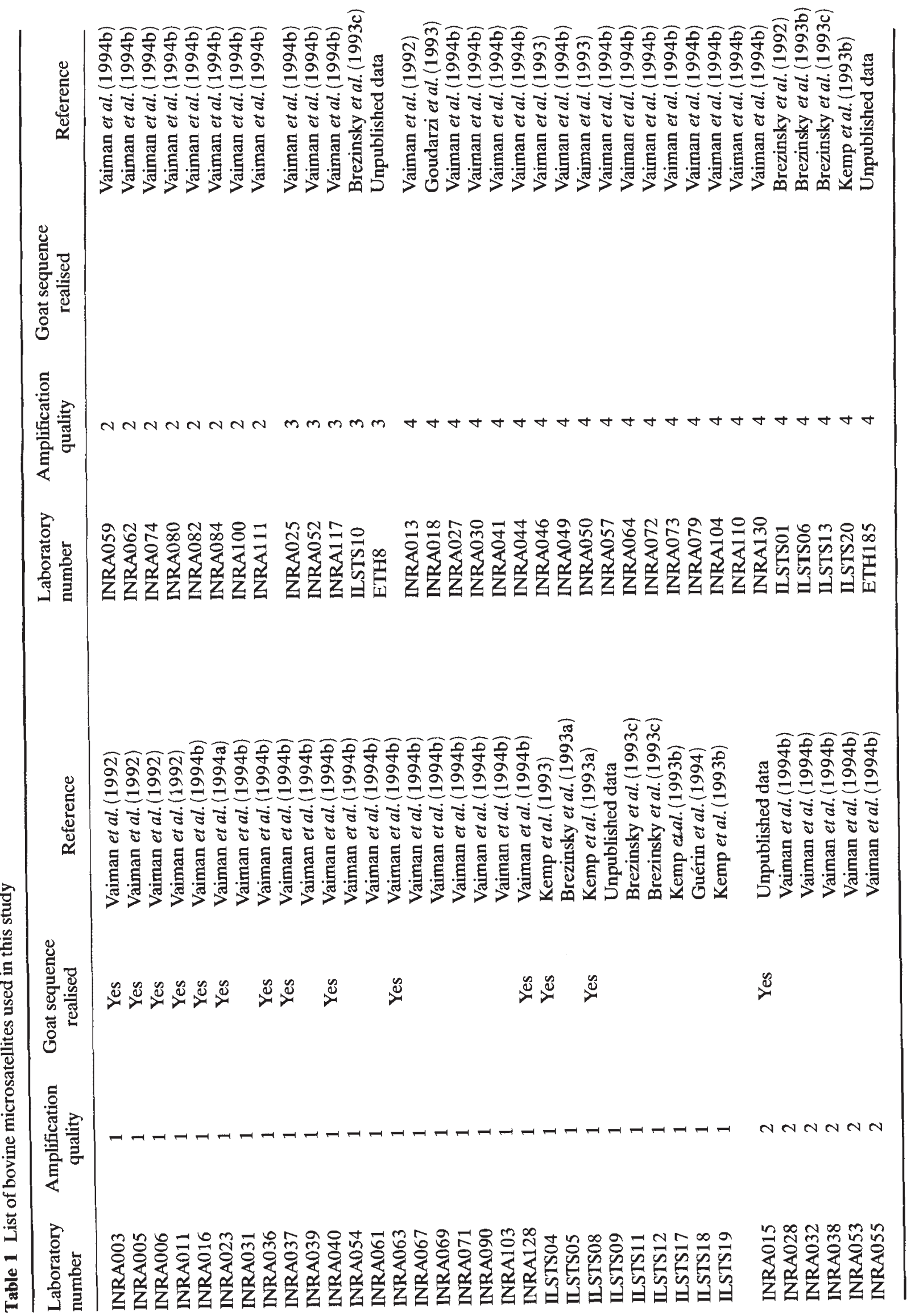


2: one prominent band in a relatively weak smear; 3 : different bands of various sizes; 4 : smear of weak bands or no amplication at all). The counts of loci in decreasing quality of amplification were 29 (41.4 per cent), 14 (20.0 per cent), 5 (7.1 per cent) and 22 (31.4 per cent). A goat PCR product of the expected size could be obtained in 43 cases (61.4 per cent, quality 1 and 2 ). Peculiarly, primers for INRA015, although designed from the bovine sequence, could give an amplification product with goat DNA but not with bovine.

Fourteen goat microsatellites were cloned after PCR amplification with the bovine primers, and sequenced. Figure 1 shows the sequence comparison between cattle and goat for the microsatellite flanking sequences resulting in an average percentage of similarity of 85.6 per cent $( \pm 12.35$ per cent $)$. Most of the sequences were essentially conserved with only some point mutations and small deletions of a few base pairs. Two exceptions are INRA003 and INRA040, for which deletions of 30 and $40 \mathrm{bp}$ in the bovine sequences, respectively, differentiate the two species. These two deleted sequences were compared with the GenBank and EMBL databases, but no significant similarity could be detected with other known DNA fragments.

INRA003, INRA006 and INRA023 were previously cloned and sequenced in sheep (Vaiman et al., 1994a). Between cattle and sheep, INRA006 and INRA023 are well conserved whereas for INRA003, the ovine sequence is very similar to the caprine (Fig. 1, INRA003), including the $30 \mathrm{bp}$ insertion mentioned above that is lacking in the bovine sequence. This is consistent with the hypothesis of a closer phylogenetic relationship between goat and sheep than between cattle and either of these species (Randi et al., 1991).

To extend interspecific sequence comparison, INRA023 was cloned from Nilgaï, classically considered as a close relative of cattle, Himalayan Tur, closely related to goats, and the fallow deer (Cervidae) as a species exterior to the Bovidae family. Comparison of similarity coefficients is summarized in Table 2 . Although only one system was considered, results display perfect consistency with published phylogenetic distances in the Order Artiodactyla. The fallow deer is the most distant to other species $(0.79$ on average). The highest coefficients are found between Bos and Boselaphus (0.95) and between the two members of the genus Capra (0.93) whereas these two subgroups are relatively close $(0.92)$.

\section{Study of polymorphism}

Twenty microsatellite loci known by somatic cell mapping to be spread all over the bovine genome (Vaiman et al., 1994b), were chosen for a study of poly- morphism in the goat. These loci were selected because they have been extensively used in cattle for population studies (Moazami-Goudarzi et al., 1994). Data on a sufficient panel of animals were obtained for nine loci (Table 3). The number of alleles and PIC observed are indicated in Table 3. Allele sizes were estimated approximately by a parallel run of a M13 mp18 sequencing reaction. No evidence of correlation could be found between the bovine and the caprine PIC or number of alleles. Examples of disparate diversities are given by microsatellites INRA016 and INRA128 (not shown in the table) which were monomorphic in goat (nine and five alleles in cattle, respectively) and microsatellite INRA011, for which more than 20 alleles were visible in goat (only eight alleles were visible in cattle). In all the cases where such differences in polymorphism are observed, sequence analysis suggests that interruption(s) in the dinucleotide repeat in one of the species is correlated with a drop in the number of alleles. The longest uninterrupted repeat in the goat is of only six TG for INRA016, six CA for INRA128 vs. 18 and 14 in cattle, respectively. This result is consistent with a frequent observation of polymorphism loss when using interspecific priming of microsatellites (Kondo et al., 1993). To explain this frequent observation, one can suggest that while the screening in the first species is realized in stringent conditions to isolate exclusively large TG repeats, the extension to another species does not experience the same constraints and may result in shortened or altered TG repeats in this second species, even though the locus is maintained at the homologous chromosomal location.

In one case (INRA011), we observed an increase in the number of alleles in goat. At this locus, the bovine dinucleotide TG repeat is interrupted by a TA whereas in goat this interruption is absent. In vitro studies demonstrated that polymerase slippage is probably the predominant mechanism to generate new alleles in simple sequence repeats (Schlötterer \& Tautz, 1992). Most probably, interruptions in the stretch of the microsatellite dinucleotide repeat can prevent polymerase slippage. To our knowledge, this study, based on interspecific comparisons of sequences and polymorphism gives one of the first indications that polymerase slippage can favour the creation of new microsatellite alleles in an in vivo system. These considerations suggest that interspecific study of microsatellite polymorphisms can give valuable insights into the stability of short repetitive sequences in the genome of mammals. This issue could be important in the interpretation of trinucleotide repeat expansions, correlated with certain human diseases. In at least one case, the expansion of the repeat linked to the disease is correlated with the presence of a perfect run 
of CAG repeats whereas individuals bearing an imperfect stretch of repeats (interrupted with CAA triplets) do not undergo triplet expansion (J. L. Mandel, personal communication).
Polymorphism was also extensively tested for three systems (INRA005, INRA006 and INRA023) in six different goat breeds. In Alpine and Saanen the number of animals used to calculate the frequencies
JNRAOO

goat

cattle

sheep

INRA 005

goat

cattle

INRADO 6

goat

cattle

INRADI1

goat

cattle

INRAD 15

goat

cattle

INRAOI6

goat

INRA 023

cattle

INRA0 36

goat

cattle

INRA 037

goat

cattle

INRAO4D

goat

cattle

INRA0 63

goat

goat

\section{INRA1 28}

goat

cattle

ILSTSOOA

goat

ILSTS008 goat

goat

CTGGMGGTGTGTGACCCCATI2AATTCCACTCCTACGTCCT (CA) \& CCCCCTCCGCCGCTCCCAACGCT . GT . CCCCACCT. CCACCAGATTTCCACGTCCATGT TGAAAAAC . TAAAGT

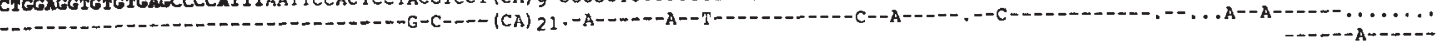

CCTTCACC. AGCTTCCTCCGCCGGGCTCACCACTAGCTCCTAGTCACACCTTCGACTCT2ACA

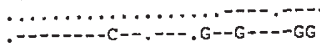

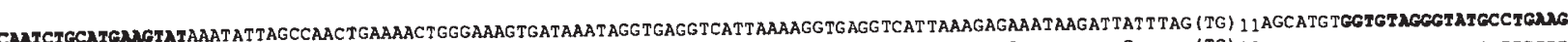
CMATCTGCATCANGTATAAATAT TAGCCAACTGAAAACTGGGAAAGTGATAAAT AGGTGAGGTCATIAAAAGGIGAG

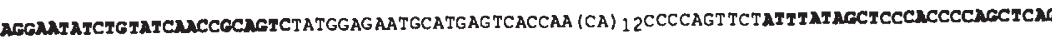

CGAGTITCTTICCTCGTGGTAGCCTGGGGCATCAGGAGATTCTCCTCCCCCC TGCGCTCCACCATT (CA) $27 \ldots$... TCCAGTTCAAGATTGAGGGGTAGAAAAAGAAAGAGGGGCAAAAA CGAGTITCTTICCTCGTGGTACCCTGGGCATCAGGAGATTCTCCTCCCCCCTGCGCTCCACCATT (CA) 27 . . .

AAGTGGGGAAGGAAAAGAGGGAGGGATAGGAAGAGTTGCTAACGAMGATGTCCCGAGC

AAGJGGGAAGGAAARGAGGACGGATAGGAGRGT

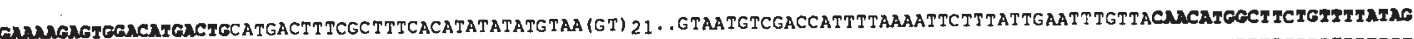
Gun

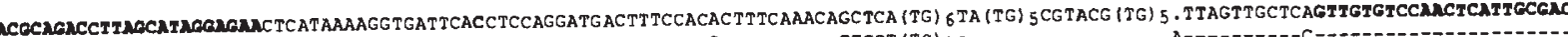
MCесламСТ

TAACTACACEGTGTMGATGANCTCTAATGCT TTCACCTGGCTGACTTCCCCTTCCTTCTGCTTCAGTTTCT AATTTCCCTTCTGACTGGTACT2CCTCT.C (GT) 18AAATTCATTTACCA na

TCAAGTCTTTTTGGTCTCATTGGCATTTCCTT TTTGGNATITATCTZGTACCTCTACTC

TCAAGTCTTITTGGICICATTGGCATTICCTITI

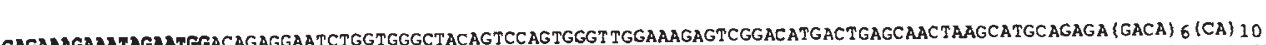
GAGA

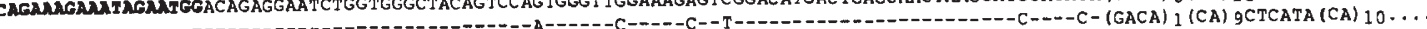

AATGTATTCANGNCCACCTCACATCTTTT

A

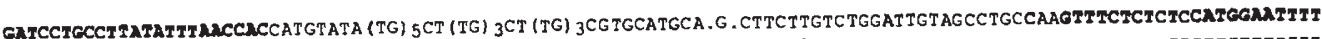

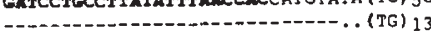

....---T-A-GCTCA-

TCAGTCTCCMCGMGAGMAMACGTTACAGAACAGAT. , GGCTAAAGGGATGTAAGAACC (GT) 17 AACTCATATCCCAGGCT. AAAGGTATTTGAGAACCGGGTCC (GT) 15. AACTCATATC

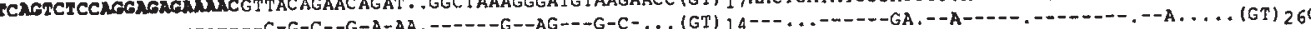

CCAGGCTAAAGGGATTTGAGATCCATGCCA (TG) g? ACACAATCATCCCCAGGGCAGA

........................... (TG) 9 ATtTGCACMACCTAMUTCTAACCAAGT TCCCCTACAAAGTAACGACATAAACGT ACAAGAGAGTGAAA (CA) $11 \ldots \ldots$..... CAAAATAATCCTATCCCTGAGTTCTT .CTAACTTTTT ATAGTACTTTCCAAACTTTCT TCCAACCATT TCFGTGGTTY

A

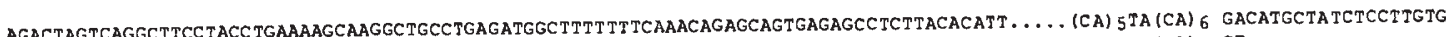
A

GTCTTCACTGTACCATCTCCTGTCCGSTCCTTR

CTTAAMATCTGTCTITCTICCTTGC (CA) 11 CG (CA) 22 CCCACTACTTCTGTTGTTGCTCTGGAGAAACCTAATACACACTA

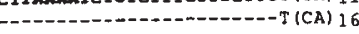

AacAGTGAGTGMCGT TGGCGAGTTGAGTATAATCCTTGGTTGTGTG. TTGAGTCAGTGGCAGTGTCTCCCACATCTAATTTA (TG) 11 CATATGCACACATGTGCAACCTTAAAAGGTAGT

ATGCAGCAGGTGCTTCACTTGACCCCNGNULTCCATEMTTC

Fig. 1 Alignment of nucleotide sequences between goat (upper sequence) and cattle (lower sequence) for the 14 microsatellites of the study. Primers are indicated in bold characters. Gaps (.) have been placed to maximize the homology. Dashes (-) correspond to nucleotides which are identical between goat and cattle. For microsatellite INRA003, the sheep sequence corresponding to the $30 \mathrm{bp}$ insertion is represented (see text). 
Table 2 Coefficients of similarity in INRA023 sequence between different Artiodactyla species

\begin{tabular}{lccccc}
\hline & B.tragocamelus & B. taurus & C. hircus & C. cylindricornis & Cervus dama \\
\hline Boselaphus tragocamelus & 1 & 0.95 & 0.93 & 0.93 & 0.80 \\
Bos taurus & & 1 & 0.92 & 0.92 & 0.83 \\
Capra hircus & & & 1 & 0.93 & 0.76 \\
Capra cylindricornis & & & & 1 & 0.77 \\
Cervus dama & & & & 1 \\
\hline
\end{tabular}

Table 3 Comparison of polymorphism between cattle and goat

\begin{tabular}{lcccccc}
\hline $\begin{array}{l}\text { Laboratory } \\
\text { number }\end{array}$ & $\begin{array}{c}\text { Number of } \\
\text { alleles in goat }\end{array}$ & $\begin{array}{c}\text { Average size } \\
\text { in goat }\end{array}$ & PIC in goat & $\begin{array}{c}\text { Number of } \\
\text { alleles in cattle }\end{array}$ & $\begin{array}{c}\text { Average size } \\
\text { in cattle }\end{array}$ & PIC in cattle \\
\hline INRA003 & 3 & 188 & 0.39 & 10 & 200 & 0.77 \\
INRA005 & 5 & 139 & 0.56 & 3 & 150 & 0.51 \\
INRA006 & 12 & 100 & 0.82 & 7 & 105 & 0.54 \\
INRA011 & 20 & 150 & 0.92 & 8 & 200 & 0.41 \\
INRA023 & 12 & 210 & 0.79 & 12 & 220 & 0.77 \\
INRA036 & 9 & 170 & 0.72 & 4 & 170 & 0.47 \\
INRA040 & 9 & 220 & 0.83 & 44 & 205 & 0.87 \\
INRA063 & 6 & 170 & 0.72 & 7 & 180 & 0.46 \\
ILSTS08 & 4 & 180 & 0.29 & 4 & 179 & 0.57 \\
\hline
\end{tabular}

was above 30 . This number was $16,12,11$ and 10 for the Poitevine, Guadeloupean, Guinean and Sahelian breeds, respectively. The frequencies are reported in Table 4. A dendrogram was tentatively built with these frequencies using the Nei standard distance (Fig. 2), giving a first molecular observation about the proximity of goat breeds. Except for the Sahelian breed, the dendrogram results in data consistent with the geographical repartition of the breeds. Three local French breeds (Alpine, Saanen and Poitevine) show an expected close relationship as with two other breeds (Guadeloupean and Guinean). The unexpected position of the Sahelian breed is probably the result of the low number of individuals (10) used to calculate the allelic frequencies. The tight relationship observed between the Guinean and Guadeloupean breeds is probably explained by the known African origin of the Guadeloupean goat, imported to the French West Indies during the 19 th century.

The relatively high number of point mutations differing between cattle and goat is consistent with those described by others for Artiodactyla (Stallings et al., 1991). The phylogenetic divergence between the Bovinae and Caprinae lineage is estimated to have occurred during the early Miocene (14-17 Myr) (Simpson, 1984; Randi et al., 1991; Allard et al.,
1992), which allows the calculation of a global divergence rate for neutral nucleotide positions of 0.93 per cent $\left( \pm 0.23\right.$ per cent) $\mathrm{Myr}^{-1}$, higher than the mammalian average of 0.5 per cent $\left( \pm 0.1\right.$ per cent) $\mathrm{Myr}^{-1}$ (Wilson et al., 1987) but substantially higher than that found in Cetaceans of 0.09 per cent $( \pm 0.05$ per cent) $\mathrm{Myr}^{-1}$ (Schlötterer et al., 1991).

\section{Example of use in parentage testing}

Three different microsatellites (INRA006, INRA023 and INRA005) were used in parentage control in goat families belonging to three different breeds (Poitevine, Saanen and Alpine; Fig. 3), giving satisfactory results. The exclusion probabilities were calculated according to Hanset (1975), giving 0.75 for INRA006, 0.67 for INRA023 and 0.58 for INRA005. The cumulated exclusion probability was 0.89 . As INRA023 and INRA006 are located on the same bovine and ovine chromosomes (BTA3 and OAR1, respectively; Vaiman et al., 1994a), other markers will be necessary to obtain a perfectly reliable exclusion probability. However, preliminary distance calculations on a limited number of goat families suggest that the distance separating the two loci is over $30 \mathrm{cM}$, confirming mapping data obtained in cattle and in sheep (Vaiman et al., 1994a). 
Table 4 Comparison of allelic frequencies in different goat breeds

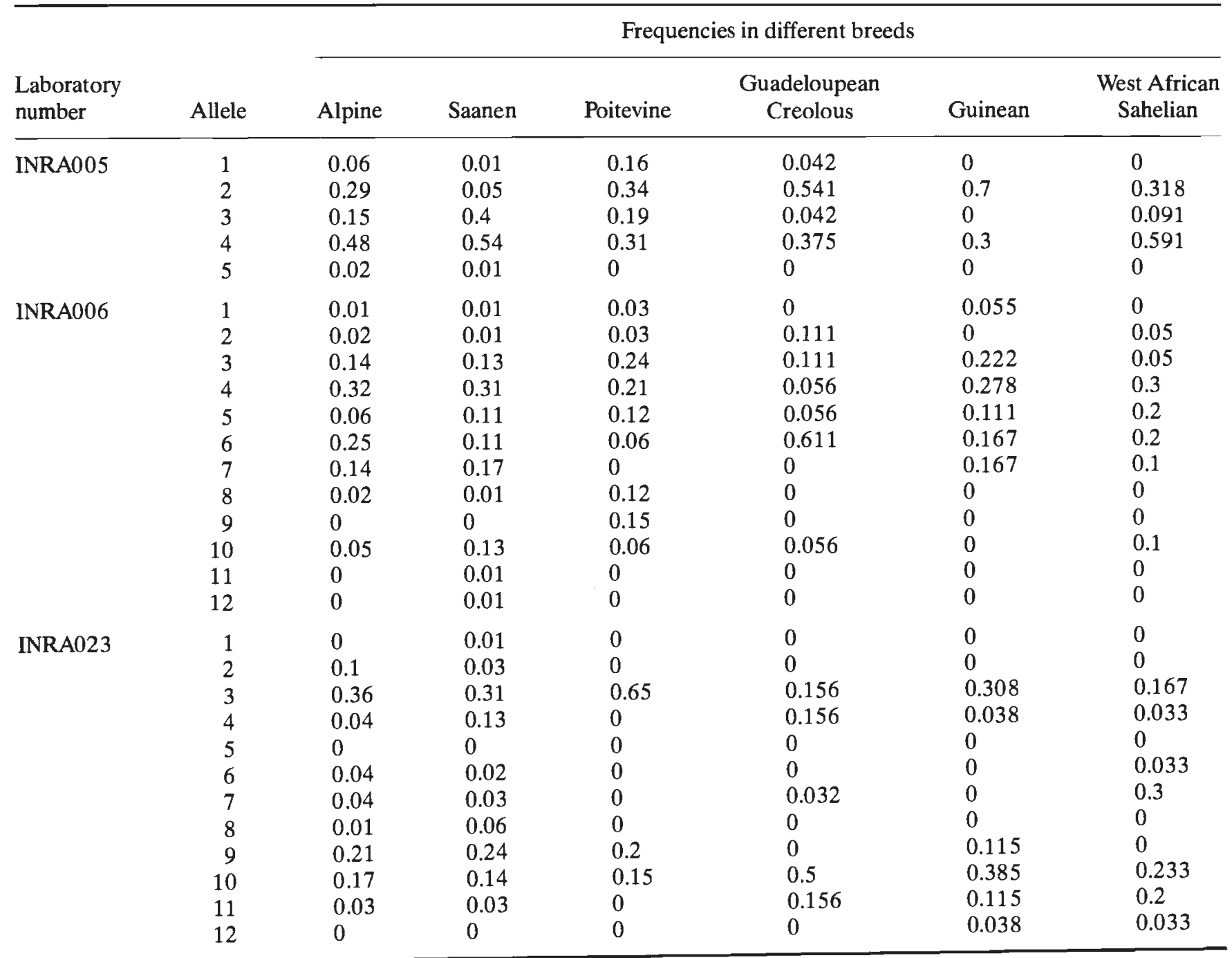

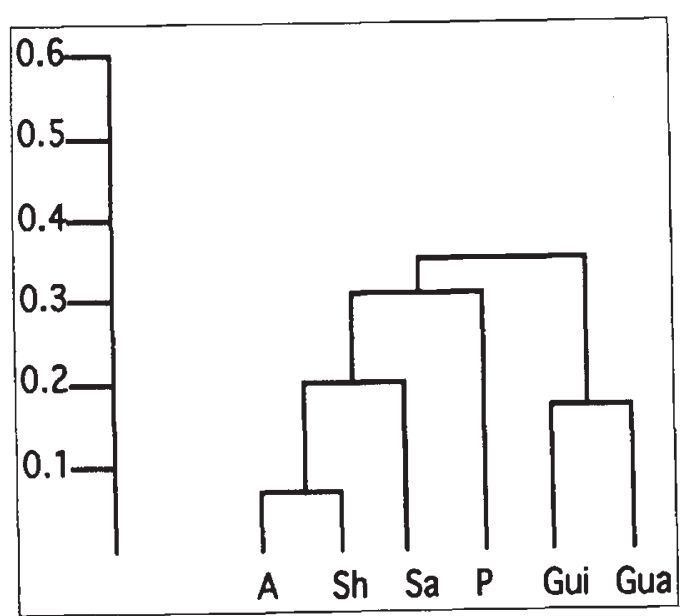

\begin{tabular}{|c|ccccc|}
\hline & A & Sa & P & Gua & Gui \\
\hline Alpine & & & & & \\
Saanen & 0.148 & & & & \\
Poitevine & 0.227 & 0.236 & & & \\
Guadelupean & 0.158 & 0.563 & 0.587 & & \\
Guinean & 0.158 & 0.462 & 0.284 & 0.176 & \\
Sahelian & 0.080 & 0.246 & 0.471 & 0.274 & 0.264 \\
\hline
\end{tabular}

Fig. 2 Matrix of genetic distances between six goat breeds using microsatellite allelic frequencies based on the UPGMA method. A dendrogram is drawn according to the data of Table 4. 

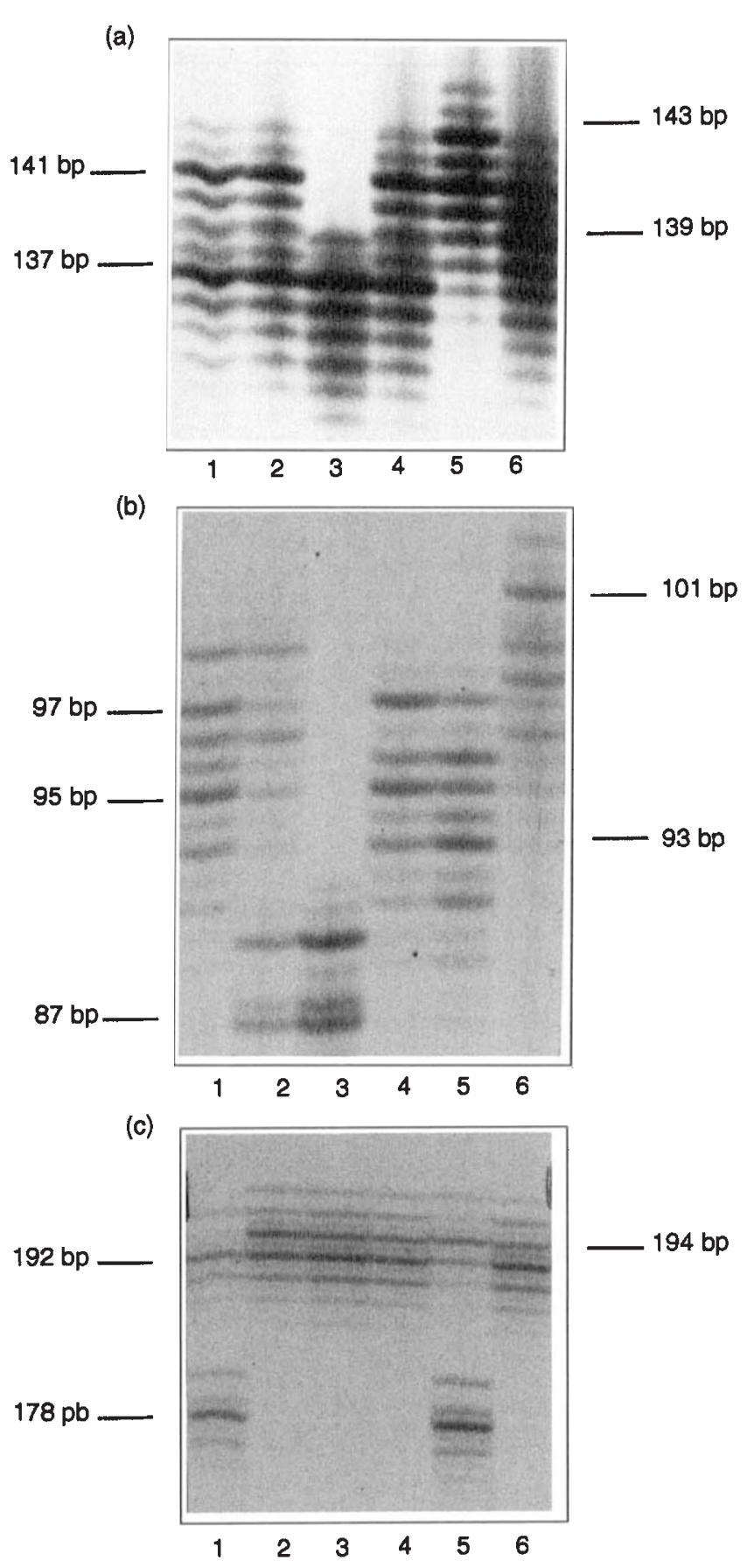

Fig. 3 Parentage analysis for a family of goats using the three microsatellite systems INRA005 (a), INRA006 (b) and INRA023 (c). Lanes 1, 2, 3 correspond to dam, offspring and sire in one putative family and 4, 5, 6 to dam, offspring and sire in another putative family. As revealed by the three systems, filiation is compatible in the first family and incompatible in the second, with a nonparental allele in lane 5 for INRA005 and INRA023, and the absence of the $99 \mathrm{bp}$ allele in lane 5 for INRA006.
In conclusion, the use of bovine microsatellites in the goat seems to be a very powerful and promising approach for providing new tools for genome analysis in this species. As shown above, microsatellites appear particularly useful for establishing registered pedigrees in the goat, which is the first prerequisite to outline selection patterns. Moreover, as selection pressure was less intense in goat than in cattle, improvement of breeds based on genetic markers can probably be more easily achieved in caprine than in bovine breeds. Different biological characteristics of goat (relatively short generation time, lower farming costs, existence of described QTL) make this species an attractive animal model for studying the feasibility of marker-assisted selection schemes and strategies eventually of use in bovine breeding, aside from its own economical interest.

\section{Acknowledgements}

We thank Drs Patrice Martin and Hubert Levéziel for constant interest and support during this work and Dr Juan Medrano for critical reading of the manuscript and suggestions. L.P. is a doctoral fellow of the French Ministère de la Recherche et de la Technologie.

\section{References}

ALLARD, M. W., MIYAMOTO, M. M., JARECKI, L., KRAUS, F. AND TENNANT, M. R. 1992. DNA systematics and evolution of the Artiodactyl family Bovidae. Proc. Natl. Acad. Sci. U.S.A., 89, 3972-3975.

BARENDSE, W., ARMITAGE, S. M., KIRKPATRICK, B. W., MOORE, S. S., GEORGES, M., WOMACK, J. E. AND HETZEL, J. 1993a. A genetic map of index DNA loci on bovine chromosome 21 . Genomics, 18, 598-601.

BARENDSE, W., ARMTTAGE, S. M., RYAN, A. M., MOORE, S. S., CLAYTON, D., GEORGES, M., WOMACK, J. E. AND HETZEL, J. 1993b. A genetic map of DNA loci on bovine chromosome 1 . Genomics, 18, 602-608.

BOTSTEIN, D., WHITE, R. L., SKOLNICK, M. AND DAVIS, R. W. 1980. Construction of a genetic linkage map in man using RFLP. Am. J. Hum. Genet., 32, 314-331.

BREZINSKY, L., KEMP, S. J. AND TEALE, A. J. 1992. ILSTS001- a polymorphic bovine microsatellite. Anim. Genet., 23, 81 .

BREZINSKY, L., KEMP, S. J. AND TEALE, A. J. 1993a. Five polymorphic bovine microsatellites. Anim. Genet., 24, 75.

BREZINSKY, L., KEMP, S. J. AND TEALE, A. J. 1993b. ILSTS005- a polymorphic bovine microsatellite. Anim. Genet., 24, 73.

BREZINSKY, L., KEMP, S. J. AND TEALE, A. J. 1993c. ILSTS006- a polymorphic bovine microsatellite. Anim. Genet., 24, 73.

CORNALL, R. J., AitMAN, T. J., HEARNE, C. M. AND TODD, J. A. 1991. The generation of a library of PCR-analyzed microsatellites variants for genetic mapping of the mouse genome. Genomics, 10, 874-881.

CROOLMANS, R. P. M. A., VAN KAMPEN, A. J. A., VAN DE POEL, J. J. AND GROENEN, M. A. M. 1993. Highly polymorphic microsatellite markers in poultry. Anim. Genet., 24, 441-443. 
CUl, X., LI, H., GORADIA, T. M., LANGE, K., KAZAZIAN, H. H., JR, GALAS, D. AND ARNHEIM, N. 1989. Single-sperm typing: determination of genetic distance between the $\mathrm{G} \gamma$-globin and parathyroid hormone loci by using the polymerase chain reaction and allele-specific oligomers. Proc. Natl. Acad. Sci. U.S.A., 86, 9389-9393.

DEVEREUX, J., HAEBERLI, P. AND SMITHIES, O. 1984. A comprehensive set of sequence analysis programs for the VAX. Nucl. Acids Res., 12, 387-395.

ELLEGREN, H., JOHANSSON, M., SANDBERG, K. AND ANDERSSON, L. 1992. Cloning of highly polymorphic microsatellites in the horse. Anim. Genet., 23, 133-142.

ESTOUP, A, PRESA, P., KRIEG, F., VAIMAN, D. AND GUYOMARD, R. 1993. (CT $)_{n}$ and $(\mathrm{GT})_{\mathrm{n}}$ microsatellites: a new class of genetic markers for Salmo trutta L. (brown trout). Heredity, 71, 488-496.

GEORGES, M., DIETZ, A. B., MISHRA, A., NEILSEN, D., SARGEANT, L. S., SORENSEN, A., STEELE, M. R., ZHAO, X. Y., LEIPOLD, H., WOMACK, J. E. AND LATHRoP, M. 1993a. Microsatellite mapping of the gene causing weaver disease in cattle will allow the study of an associated quantitative trait locus. Proc. Natl. Acad. Sci. U.S.A., 90, 1058-1062.

GEORGES, M., DRINKWATER, R., KING, T., MISHRA, A., MOORE, S. S., NIELSEN, D., SARGEANT, L. S., SORENSEN, A., STEELE, M. R., ZHAO, X., WOMACK, J. E. AND HETZEL, J. 1993b. Microsatellite mapping of a gene affecting horn development in Bos taurus. Nature (Genet.), 4, 206-210.

HANSET, R. 1975. Probabilité d'exclusion de paternité et de monozygotie, probabilité de similitude. Généralisation à $N$ allèles codominants. Ann. Méd. Vét., 119, 71-80.

haYes, H., PETIT, E. AND DUTRILlauX, B. 1991. Comparison of RBG-banded karyotypes of cattle, sheep, and goats. Cytogenet. Cell. Genet., 57, 51-55.

JEANPIERRE, M. 1987. A rapid method for purification of DNA from blood. Nucl. Acids Res., 15, 9611.

KAUKINEN, J. AND VARVIO, S.-L. 1993. Eight polymorphic bovine microsatellites. Anim. Genet., 24, 148.

KEMP, S. J., BREZINSKY, L. AND TEALE, A. J. 1993a. ILSTS008- a polymorphic bovine microsatellite. Anim. Genet., 24, 74.

KEMP, S. J., BREZINSKY, L. AND TEALE, A. J. 1993b. A panel of bovine, ovine and caprine polymorphic microsatellites. Anim. Genet., 24, 363-365.

KONDO, Y., MORI, M., KURAMOTO, T., YAMADA, J., BECKMANN, J. S., SIMON-CHAZOTTES, D., MONTAGUTELLI, X., GUÉNET, J.-L. AND SERIKAWA, T. 1993. DNA segments mapped by reciprocal use of microsatellite primers between mouse and rat. Mamm. Genome, 4, 571-576.

LEROUX, C., MARTIN, P., MAHÉ, M.-F., LEVÉZIEL, H. AND MERCIER, J.-C. 1990. Restriction fragment length polymorphism identification of goat $\alpha_{\mathrm{sl}}$-casein alleles: a potential tool in selection of individuals carrying alleles associated with a high level protein synthesis. Anim. Genet., 21, 341-351.
MOAZAMI-GOUDARZI, K., VAIMAN, D., MERCIER, D., GROHS, C., FURET, J. P., LEVÉZIEL, H. AND MARTIN, P. 1994. Emploi de microsatellites pour l'analyse de la diversité génétique des races bovines françaises: premiers résultats. Génét. Sél. Évol., 26, $155 \mathrm{~s}-165 \mathrm{~s}$.

MONTGOMERY, G. W., CRAWFORD, A. M., PENTY, J. M., DODDS, K. G., EDE, A. J., HENRY, H. M., PIERSON, C. A., LORD, E. A., GALLOWAY, S. M., SCHMACK, A. E., SISE, J. A., SWARBRICK, P. A., HANRAHAN, V., BUCHANAN, F. C. AND HILL, D. F. 1993. The ovine Booroola fecundity gene $(\mathrm{FeCB})$ is linked to markers from a region of human chromosome 4q. Nature (Genet.), 4, 410-414.

MOORE, S. S., BARENDSE, W., BERGER, K. T., ARMITAGE, S. M. AND HETZEL, D. J. S. 1992. Bovine and ovine DNA microsatellites from the EMBL and GENBANK databases. Anim. Genet., 23, 463-467.

RANDI, E., FUSCO, G., LORENZINI, R., TOSO, S. AND TOSı, G. 1991. Allozyme divergence and phylogenetic relationships among Capra, Ovis and Rupicapra (Artyodactyla, Bovidae). Heredity, 67, 281-286.

SCHLÖTTERER, C., AMOS, B. AND TAUTZ, D. 1991. Conservation of polymorphic simple sequence loci in cetacean species. Nature, 354, 63-65.

SCHLÖTTERER, C. AND TAUTZ, D. 1992. Slippage synthesis of simple sequence DNA. Nucl. Acids Res., 20, 211-215.

SIMPSON, G. G. 1984. Artiodactyls. In: Anderson, S. and Jones, J. K., Jr (eds) Orders and Families of Recent Mammals of the World, pp. 563-588. John Wiley and Sons, New York.

STALLINGS, R. L., FORD, A. F., NELSON, D., TORNEY, D. C., HILDEBRAND, C. E. AND MOYZIS, R. K. 1991. Evolution and distribution of $(\mathrm{GT})_{\mathrm{n}}$ repetitive sequences in mammalian genomes. Genomics, 10, 807-815.

VAIMAN, D., IMAM-GHALI, M., MOAZAMI-GOUDARZI, K., GUÉRIN, G., NOCART, M., GROHS, C., LEVEZZIEL, H. AND SAlDI-MEHTAR, N. 1994a. Conservation of a syntenic group of microsatellite loci between cattle and sheep. Mamm. Genome, 5, 310-314.

VAIMAN, D., MERCIER, D., MOAZAMI-GOUDARZI, K., EGGEN, A., CIAMPOLINI, R., LÉPINGLE, A., VELMALA, R., KAUKINEN, J., VARVIO, S.-L., MARTin, P., LEVÉzIEL, H. AND GUérin, G. 1994b. A set of 99 cattle microsatellites: characterization, synteny mapping and polymorphism. Mamm. Genome, 5, 288-297.

VAIMAN, D., OSTA, R., MERCIER, D., GROHS, C. AND LEVÉZIEL, $H$. 1992. Characterization of five new bovine dinucleotide repeats. Anim. Genet, 23, 537-541.

WEISSENBACH, J., GYAPAY, G., DIP, C., VIGNAL, A., MORISSETTE, J., MILlASSEAU, P., VAYSSEIX, G. AND LATHROP, M. 1992. A secondgeneration linkage map of the human genome. Nature, 359, 794-801.

WILSON, A. C., OCHMAN, H. AND PRAGER, E. M. 1987. Molecular time scale for evolution. Trends Genet., 3, 241-247. 